\title{
Restoration of degraded mountain pastures of the Central Caucasus by targeted sowing of seeds of perennial grasses
}

\author{
Eduard Soldatov ${ }^{1}$, Sergey Dzhibilov ${ }^{1}$, Irina Soldatova ${ }^{1}$, and Lyudmila Guluyeva ${ }^{1, *}$ \\ 1Vladikavkaz Scientific Center of the Russian Academy of Sciences, 1, Williams Str. Suburban \\ district, with. Mikhailovsky, North Ossetia-Alania, Russia
}

\begin{abstract}
The unsystematic use of mountain pastures with overgrazing of grasses has led to a change in the ecological balance of agrolandscapes, in which $80-85 \%$ of the Central Caucasus lands have turned into a state of varying degrees of degradation. In these cases, an important measure in the restoration of degraded mountain forage lands is the sowing of perennial grasses into sparse grass and on bare soil, which increases stiffness. Therefore, the development and creation of a seeder for targeted seeding of grass mixtures in solving the problem is relevant. The authors of the article have developed a new resource-saving way to improve mountain forage lands using a modernized seeder. Tests and studies were carried out at a mountain hospital, located on the southeastern exposition of the Dargavs depression of the North Ossetia-Alania, at an altitude of $1650 \mathrm{~m}$ above sea level. It was found that at a concentration of $17.2 \mathrm{MJ}$ of energy in $1 \mathrm{~kg}$ of dry matter of feed, the total collection in the control plot was $29.7 \mathrm{GJ}$, and in the seeded experimental field - 85.3 GJ. At the same time, the formation of a dense sod with the accumulation of $104.2 \mathrm{c} /$ ha of root mass is the main factor in the environmental sustainability of mountain agrolandscapes, ensuring environmental safety
\end{abstract}

\section{The relevance of the topic}

Currently, the management of meadow pasture potential of mountain forage land is not fully utilized. Climate change, combined with a violation of environmental management technologies, are key factors in the ecological state of mountain agricultural systems [1]. As a result of this, land degradation occurs, erosion is formed, which to varying degrees covers more than $80 \%$ of mountain forage land.

In this state, valuable, highly nutritious, well-eaten plants are inhibited, which leads to the loss of loose shrubs and legumes from the grass stand, which are replaced by dense shrubs and rhizomes, they are replaced by weeds and poisonous ones, bare sections of the soil surface are formed, provoking the development of erosion processes [2 ].

In areas with sparse grass stand, soil erosion reaches 500-900 m3 / ha, whereas under normal erosion, the erosion does not exceed the rate of soil formation, amounting to 2-3 $\mathrm{m} 3$ / ha. Such processes can be opposed by the only natural factor - vegetation, whose soil-

*Corresponding author: luda_gulueva@mail.ru 
protective role largely depends on the species composition and projective cover of the grass stand.

So, cereal-bean herb mixtures in the ratio (3-4): 1 form a powerful root system that provides a dense turf cover of the soil, contributing to mechanical stability [3]. The projective coating directly affects the amount of erosion, since it protects the surface of the soil from a direct drop of raindrops on the ground, reducing its kinetic energy, preventing a soil spike.

Strongly pastured pastures, as a rule, are located on the southern, riverine parts of slopes and waste arable lands, where slitting and fertilizing do not always give a positive result when restoring grass, preventing surface runoff and soil erosion [4-5]. However, serial models of equipment for the implementation of this technological process of surface improvement of mountain forage lands do not exist. Currently, for sowing grasses, use SZ-3.6A overall graingrass seeders; SZT-3.6A; SZPP-4, the use of which in the mountain zone is difficult. On mountain slopes, as a rule, the degraded parts are switched off from use for self-healing.

The restoration of degraded mountain fodder land by the method of disabling from use (providing recreation) takes a long period [6]. In the first 1-2 years, weeds and weeds develop, then rhizome grasses grow. After this, the area is covered with perennial cereal perennial grasses, and perennial leguminous grasses grow at the same time. This is a long process that takes up to 10 years, which is economically disadvantageous, especially for developing farms [7].

To quickly restore degraded mountainous fodder land and increase soil fertility, it is of great importance to create a species structure of grass stand with a powerful root system of loose-growing cereals and legumes that contribute to the creation of a small-clumped soil structure and ecological sustainability of agroecosystems. Therefore, the development and creation of a seeder for targeted seeding of grass mixtures in solving the problem is relevant [8].

The aim of the research in solving this problem was to test a prototype seeder for targeted sowing of seeds of perennial native grasses, which reduces the consumption of seeds, their close contact with the soil cover when exposed to rolling rollers on thinned and exposed sections of mountain forage land.

The scientific novelty of the research is that for the first time the chisel cultivator is equipped with removable working bodies for automatic, targeted sowing of seeds of perennial grasses on mountain forage lands, ensuring the formation of the structure of economic and botanical groups of phytocenosis, increasing productivity and environmentforming role, reducing erosion processes [9].

The research objectives included:

- to characterize the economic and botanical groups, the density and accumulation of biomass grass stand degraded mountain pasture;

- carry out restoration of grass stand by methods of: natural self-seeding (providing rest) and using a prototype of a modular unit for automatic targeted sowing of seeds of perennial grasses;

- establish agro-energy and environmental efficiency of the recovery process.

The practical significance lies in the fact that targeted sowing of seeds will reduce their consumption, increase survival rate, accelerate the recovery processes of productivity and economic and botanical groups of grassland pastures [10], due to the equipment of the sowing apparatus with a support runner and a roller with a rod that regulates when driving on bare and thinned areas.

The studies were carried out in the Dargavs basin of the North Ossetia-Alania on the slope of the southern exposure with a slope of $10-12^{\circ}$. Degraded pasture $34-45 \%$ of the coverage is of grass-grass, xerosomesophytic grass, pasture type, located at an altitude of 1580-1600 $\mathrm{m}$ above sea level meadow-steppe belt. Soils are mountain meadow.Studies were conducted on six plots, with a recorded area of $360 \mathrm{~m} 2$. Two options in triplicate. The first option is 
natural seeding, and the second is the seeding of grasses by the aggregate. The plots are located across the slope randomized.

\section{Technical and operational features of the address subseeding unit}

The use of the sowing apparatus allowed to increase the productivity of mountain forage land, labor productivity, reduce the cost of seeds for sowing and create favorable conditions for agricultural workers in the mountain zone. With the use of this sowing device, the environmental stability of the slope plots to water and wind erosion is simultaneously increased.

For the first time, a new method is implemented on the chisel cultivator (Fig, 1). The cultivator is equipped with removable working bodies for automatic, targeted sowing of grass seeds on meadows and pastures of the mountain zone, providing increased agricultural productivity, reduced erosion processes and increased resistance of agrolandscapes to erosion processes [10].

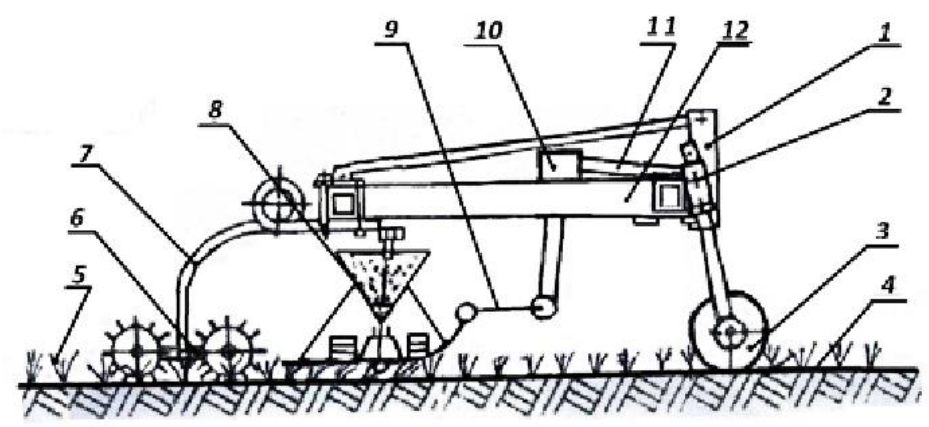

Fig. 1. A unit for sowing grass seeds on a rare phytocenosis.

1 - automatic coupler lock KCHG-2.4; 2 - adjusting device; 3- supporting and adjusting wheel; 4-bare sections; 5 - grass; 6 section packer rollers; 7 - spring racks "Viderstadt"; 8 sowing devices; 9 brackets; 10, 11-articulated traction; 12 - cultivator frame.

Known methods for sowing grass seeds including spread sowing seeds. For example, a method of sowing grass in turf on sloping lands (RF patent No. 2168294, ABB 79/02, $06 / 10 / 2001$ ), including sowing grass in an untreated turf with subsequent cultivation and simultaneous formation of rollers on the sides of the passages of the unit following the planner. However, this technical solution requires additional costs for the passes of the units and seed.

The technical result of the proposed solution is to reduce the cost of seed, improve grass stand in damaged areas [11-12]. The technical solution to the problem is that the sowing of seeds is carried out targetedly, namely in areas with damaged, weakened grass stands due to the equipment of the sowing apparatus with a support runner and a roller with a stem (Fig. 2). 


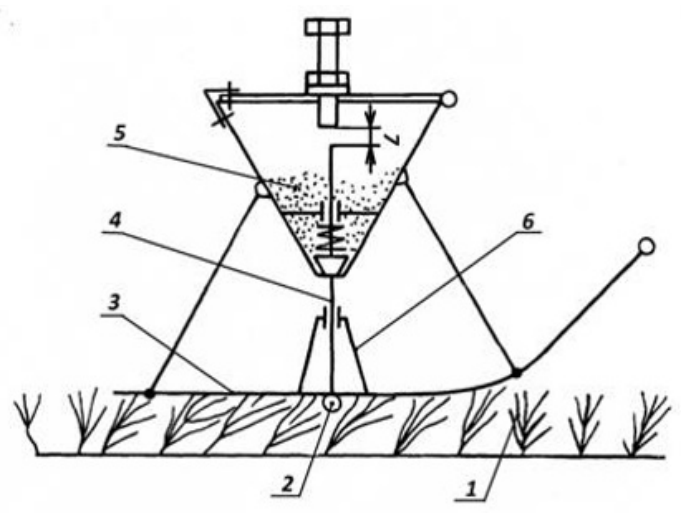

Fig. 2. The method of automatic, targeted sowing of grass seeds. 1-grass cover; 2-roller; 3-net snake ;; 4-stem; 5-seeds of herbs; 6-scatter cone.

Grass sowing is carried out in spring after growing grass cover 1 to 5-6 $\mathrm{cm}$ or in autumn (depending on the recommended seed sowing period) at the same height of grass stand. The sowing units are equipped with a net runner 3 and a support roller 32 with a stem 4 .

Targeted sowing of seeds is carried out during the transition of the runner with the support roller to the exposed or weakened area. In this case, the roller contacts the hard surface and the roller rod, rising upward, opens the seeds 5 to the exit to the spreading cone 6 . The mesh runner ensures smooth movement and stability of the sowing apparatus. When the runner with the support roller moves along the grass stand with a normal standing density of 5-6 cm in height, the rod of the roller is in its highest position, which prevents the sowing of seeds.

Example. In spring, when reaching a height of grass stand of 5-6 cm, grass was sowed on a mountain pasture with bare sections. During the movement of the sowing apparatus, equipped with a mesh runner with a support roller on the stem, sowing of seeds occurred along the exposed section. When grazing, grazing of seeds into the soil was ensured. The proposed method will reduce the consumption of grass seeds and improve the condition of the grass stand of meadows and pastures. Figure 3 shows the seeding working body assembly.

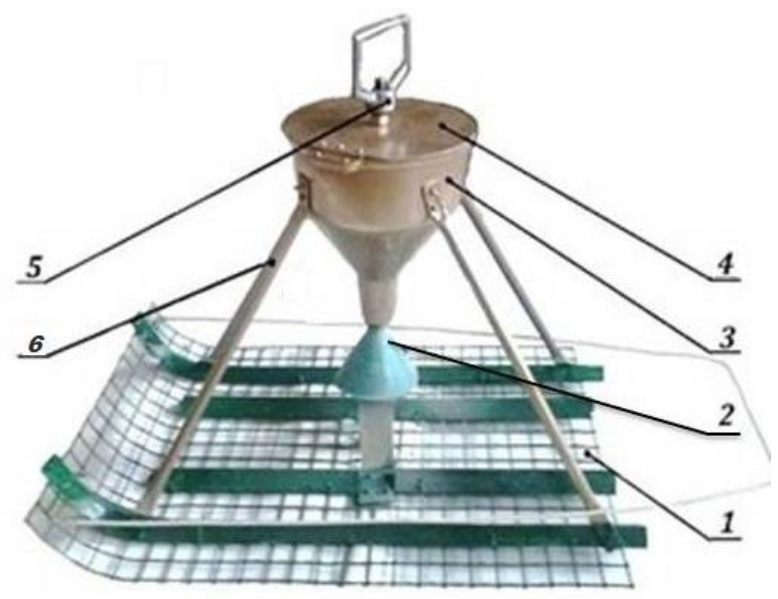

Fig. 3. Sowing working body. Where: 1 - net snake; 2 - scattering cone of seeds; 3 - seed box; 4 - a cover of a seed box; 5 - screw for adjusting the seeding rate with a handle locknut; 6 - a rack of fastening of a seed box. 


\section{Research Results}

After carrying out cultural and technical measures (cleaning stones and old people, cutting bumps, uprooting shrubs and harrowing), in the phase of the beginning of tillering, at a height of natural grass stand of $6-10 \mathrm{~cm}$, using the tested unit, the seeds of the treated fivecomponent grass mixture were sowed based on continuous sowing per 1 ha: bonfireless fire - $10 \mathrm{~kg}$; meadow fescue $-8 \mathrm{~kg}$; pasture ryegrass - $6 \mathrm{~kg}$; white clover - $4 \mathrm{~kg}$; red clover - $6 \mathrm{~kg}$, with a total weight of $34 \mathrm{~kg} / \mathrm{ha}$.

Targeted seeding of the degraded experimental field with grass coverage of $42 \%$ reduced the consumption of grass mixtures by $58 \%$ or $19.7 \mathrm{~kg}$. Seed rolling, favorable weather conditions ensured the friendly germination of seeds and the development of seedlings. Legumes, as a rule, take root well on soils poor in nutrients, since they enter into symbiosis with nodule bacteria and absorb air nitrogen, providing themselves with growth and development

[13-14].

In our studies, the survival rate of the bean component was higher than the cereal. By the end of the first year of the growing season, the proportion of the bean component during inoculation by the aggregate increased, compared to the control, from 1.5 to $38.7 \%$ (Fig. 45).

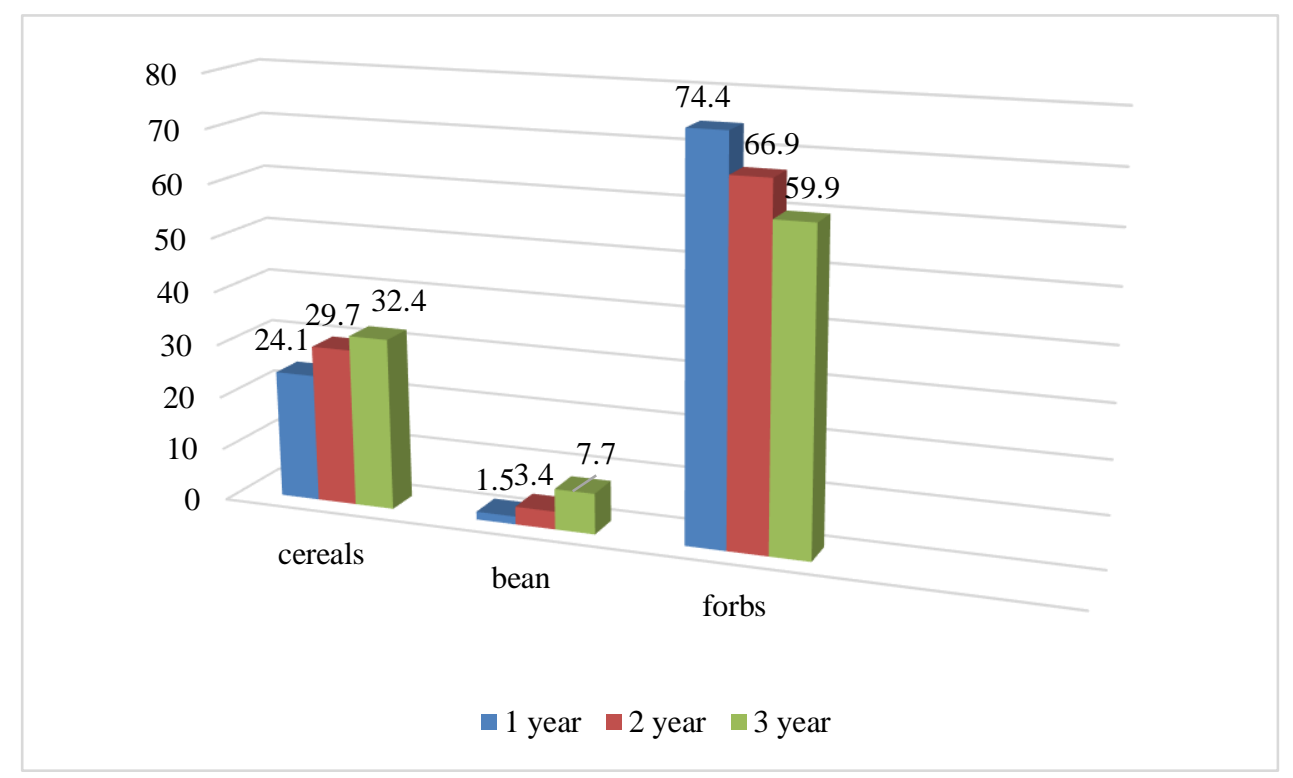

Fig. 4. Dynamics of grass elements in the control (self-seeding). 


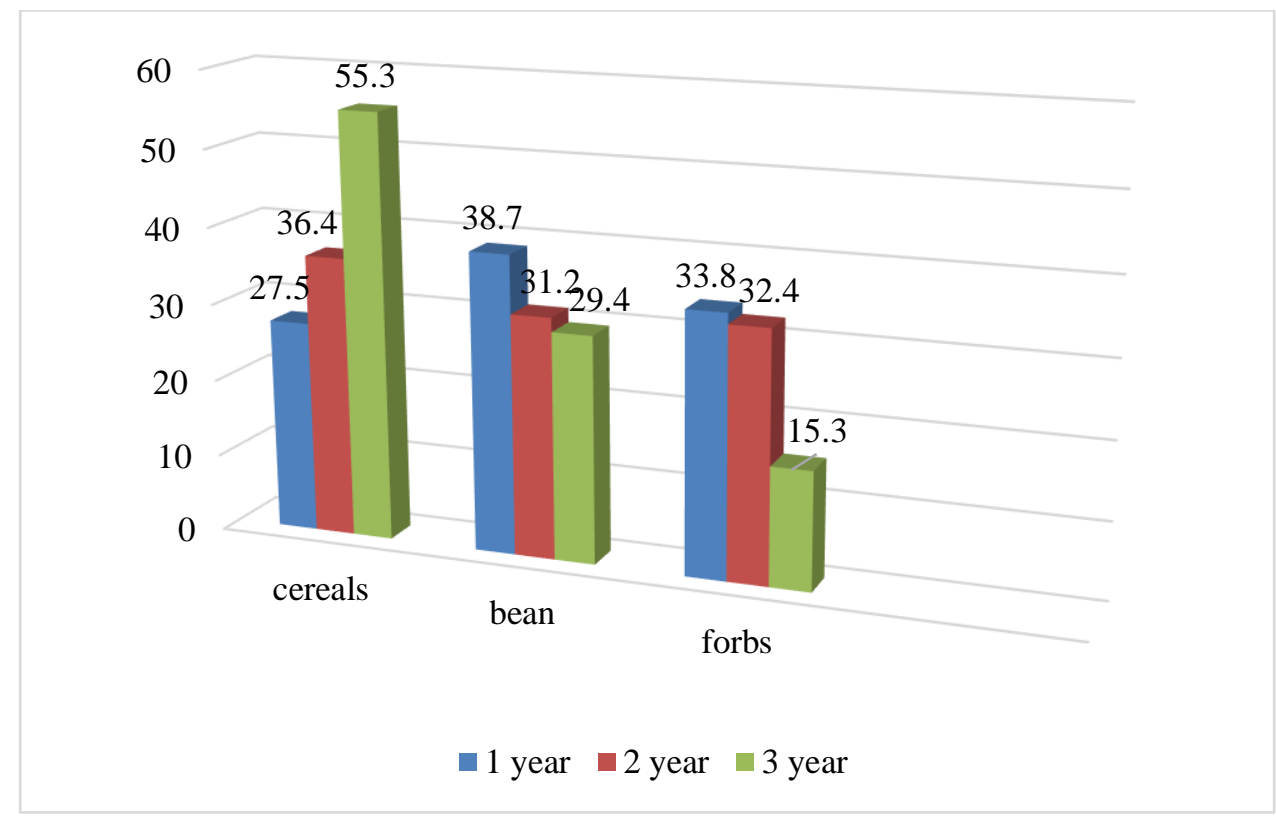

Fig. 5. Dynamics of grass elements when using the unit.

At the same time, legumes provided the best conditions for the development of cereals receiving nitrogen accumulated in the soil. This made it possible to increase the proportion of the cereal component, according to years of research, from $24.1 \%$ in the control to 36.4 $55.3 \%$, which gradually suppresses legumes, reducing their content to $29.4 \%$ in the herbage.

It has been established that perennial leguminous and cereal grasses better withstand adverse conditions and successfully jointly fight with weedy annual and biennial weeds. In the control plot, the proportion of forbs during the observation period decreased by $14.5 \%$, and the proportion of the cereal-bean component was $40.1 \%$. At the same time, grass sowing and their joint development formed a cereal-bean-forb-herb phytocenosis, where the proportion of the first two components was $84.7 \%$, reducing weed-grass from 74.4 to $15.3 \%$, although some types of forbs with good feed quality replenish the diet animals, improving the eatability of pasture feed. The change in the economic and botanical groups influenced the density of the grass stand, providing projective soil cover from 42 to $90-100 \%$, which in the first year amounted to 740 shoots per $1 \mathrm{~m}^{2}$, against 120 shoots per $1 \mathrm{~m}^{2}$ in the control plot. By the end of the growing season of the third year of observations, this indicator increased to $2370 \mathrm{pcs} / \mathrm{m}^{2}$ against $910 \mathrm{pcs} / \mathrm{m}^{2}$ in the control plot with a predominance of tall weed vegetation (Table 1).

It was revealed that changes in the grass stand influenced the accumulation of biomass of phytocenosis. So, the crop of the aboveground fodder mass, when sowing grasses, in the first year of observations was $18.2 \mathrm{cwt} /$ ha of dry weight, which is 5 times higher than in the control. During the growing season of the third year of observations (with moderate use of pastures by sheep), the yield in the sown area was $59.1 \mathrm{cwt} /$ ha of dry weight against 17.3 cwt / ha in the control.

At the same time, in the bush of cereal grass, each shoot grows its own roots, increasing the well-developed fibrous root system, especially in the upper soil layer, forming a dense sod that opposes erosion processes. In our studies, the accumulation factor of the underground mass was $104.2 \mathrm{cwt} /$ ha higher than the control variant by 2.9 times. Using the data of chemical analyzes and the corresponding energy coefficients, the cost recovery was determined by the collection of gross energy. 
Table 1. Phenological changes in phytocenosis under the influence of recovery methods.

\begin{tabular}{|c|c|c|c|c|c|c|c|c|c|}
\hline \multirow{3}{*}{$\begin{array}{l}\text { Experience } \\
\text { Options }\end{array}$} & \multicolumn{3}{|c|}{$\begin{array}{l}\text { Grass density, number } \\
\text { of shoots, pcs / m² }\end{array}$} & \multicolumn{3}{|c|}{$\begin{array}{c}\text { Accumulation } \\
\text { above ground mass, } \\
\text { cwt / ha }\end{array}$} & \multicolumn{3}{|c|}{$\begin{array}{l}\text { The accumulation of } \\
\text { underground mass, cwt/ } \\
\text { ha }\end{array}$} \\
\hline & \multicolumn{9}{|c|}{ Years of research } \\
\hline & 1 & 2 & 3 & 1 & 2 & $\mathbf{3}$ & 1 & 2 & 3 \\
\hline Control & 120 & 635 & 910 & 3.7 & 8.9 & 17.3 & 5.6 & 16.0 & 36.3 \\
\hline Seeding & 740 & 1890 & 2370 & 18.2 & 32.8 & 49.6 & 32.8 & 59.1 & 104.2 \\
\hline $\begin{array}{l}\mathrm{m}= \\
\mathrm{HCP}=\end{array}$ & & & & $\begin{array}{l}1.75 \\
3.04\end{array}$ & & & & & \\
\hline
\end{tabular}

At a concentration of $17.2 \mathrm{MJ}$ of energy in $1 \mathrm{~kg}$ of dry matter of feed, the total collection in the control plot was $29.7 \mathrm{GJ}$, and in the seeded experimental field - 85.3 GJ. With the costs of cultural and technical measures $3.2 \mathrm{GJ}$ in the control and additional sowing, amounting to 7.1 GJ in the experimental plot, you can give an agro-energy assessment of the technologies studied, which amounted to 9.3 in the control and 12.0 in the pilot, which indicates the difference in the compensation of anthropogenic costs.

Given that the cost of $1 \mathrm{GJ}$ of energy is 83 rubles, the difference between the control and the experimental field is 4465.4 rubles, and taking into account the savings of $19.7 \mathrm{~kg}$ of seeds, worth 4137 rubles, the savings is 8602 rubles / ha. In addition, the formation of dense turf with the accumulation of $104.2 \mathrm{cwt} / \mathrm{ha}$ of root mass is the main factor in the environmental sustainability of mountain agrolandscapes, ensuring environmental safety.

\section{Conclusions}

Therefore, with the accelerated restoration of degraded mountain forage land, it is necessary to sow grasses. At the same time, the use of a modular aggregate of targeted subseeding is not only economically advantageous, but also contributes to the preservation and improvement of the ecological state of mountain agrolandscapes [15-16].

\section{References}

1. M. Scotton, Science of The Total Environment 651, 3090-3098 (2019) DOI.org/10.1016/j.scitotenv.2018.10.192

2. I. Soldatova, E. Soldiers, Fertility 6(105), 63-65 (2018) DOI: 10.25680 / S19948603.2018.105.20

3. V. Ugorets, D. Soldatov, I. Soldatova, Mountain agriculture 2, 50-53 (2019) DOI: 10.25691 / GSH.2019.2.009

4. .4. A. Abaev, D. Mamiev, Scientific life 14.4(92), 406-413 (2019) DOI: 10.26088 / INOB.2019.92.30077

5. D. Mamiev, Scientific life 14.9(97), 1396-1402 (2019) DOI: 10.35679 / 1991-94762019-14-9-1396-1402

6. S. Djibilov, L.R. Guluyeva, Mountain agriculture 2, 63-68 (2019) DOI: 10.25691 / GSH.2019.2.012

7. S. Dzhibilov, L. Gulueva, E. Soldatov, I. Soldatova, IOP Conference Series: Earth and Environmental Science 403, 012068 (2019) DOI: 10.1088/1755-1315/403/1/012068

8. S. Djibilov, L. Guluyeva, I. Soldatova, N. Khokhoeva, S. Gagieva, Agrarian Bulletin of the Urals 10(189), 9-16 (2019) DOI: 10.32417 / article_5db43060bb87e6.86550212 
9. D. Mamiev, A. Abaev, A. Shalygin, Scientific life 14.7(95), 1065-1072 (2019) DOI: 10.35679 / 1991-9476-2019-14-7-1065-1072

10. Zh. Zhang, K. Yu, K. Siddique, Zh. Nan, Agricultural and Forest Meteorology 269, 257269 (2019) DOI: 10.1016/j.indcrop.2019.01.028

11. P. Török, B. Deák, E. Vida, O. Valkó, B. Tóthmérész, Biological Conservation 143, 806-812 (2010) DOI: org/10.1016/j.jnc.2011.07.006

12. S. Novoselov, A. Kuzminykh, R. Eremeev, FERTILITY 6(111), 22-25 (2019) DOI: 10.25680 / S19948603.2019.111.06

13. N. Akanova, M. Vizirskaya, FERTILITY 2(107), 57-60 (2019) DOI: 10.25680 / S19948603.2019.10.10.1.18

14. A. Kudzaev, Т. Urtaev, А. Tsgoev, И. Korobeynik, D. Tsgoev, International Journal of Mechanical Engineering and Technology 8(11), 714-720 (2017)

15. E. Kyul, A. Apazhev, A. Kudzaev, N. Borisova, Indian Journal of Ecology 44(2), 239243 (2017)

16. A. Kudzaev, T. Urtaev, A. Tsgoev, I. Korobeynik, D. Tsgoev, International Journal of Civil Engineering and Technology 8(11), 658-666 (2017) 